\title{
TEOLOGI LINGKUNGAN HIDUP DALAM PERSPEKTIF ISLAM
}

\author{
Ahmad Khoirul Fata \\ Institut Agama Islam Negeri Sultan Amai Gorontalo \\ Email: cakfata@gmail.com
}

\begin{abstract}
The damage of nature is believed to be derived from the man, the human mindset placing themselves as the life center (anthropocentrism). In this context the teachings of the monotheistic religions are often accused of having a major contribution for establishing the anthropocentrism paradigm with the doctrine of human superiority over nature. This paper attempts to trace "the source track of anthropocentrism" in the teachings of Islam in the form of man as a vicegerent on earth. Tracing various texts of Islam (especially the Quran) reveals that man's position as a vicegerent on earth is not a blank check for people to vent all their passion for nature. Humans are created with various advantages allowing themselves to be caliph, but the position was given by God to human beings completed with all the assigned tasks. The tasks make the concept of the caliphate on earth not supporting exploitative anthropocentrism to nature.
\end{abstract}

Kerusakan alam diyakini bersumber dari diri manusia, yaitu pola pikir manusia yang menempatkan dirinya sebagai pusat kehidupan ini (antroposentrisme). Dalam kaitan ini ajaran agama-agama monoteis sering dituduh memiliki kontribusi besar bagi pembentukan paradigma antroposentrisme dengan doktrin keunggulan manusia atas alam. Tulisan ini mencoba menelusuri "jejak-jejak sumber antroposentrisme" dalam Islam berupa ajaran manusia sebagai khalifah di atas bumi. Dari penelusuran atas berbagai teks Islam (terutama dalam al Quran), diketahui bahwa posisi manusia sebagai khalifah di bumi bukanlah cek kosong bagi manusia untuk melampiaskan segala hasratnya terhadap alam. Manusia memang diciptakan dengan berbagai kelebihan yang menjadikan dirinya sebagai khalifah, namun posisi itu diberikan Allah SWT kepada manusia dengan berbagai tugas yang harus diembannya. Tugas-tugas inilah 
yang menjadikan konsep khalifah di bumi tidak mendukung antroposentrisme yang eksploitatif terhadap alam.

Keywords: Nature, caliph, anthropocentrism

\section{Pendahuluan}

Keamanan dan kenyamanan hidup di muka bumi kini semakin rapuh akibat eksploitasi alam yang semena-mena, tanpa menghargai kaidah ekologi dan ekosistem sebagai bagian dari hukum alam yang berlaku pasti. Prediksi para ilmuan yang tergabung di dalam Intergovernmental Panel on Cimate Change (IPCC) menyajikan perkiraan yang amat mengerikan; Selama tahun 1990-2005 telah terjadi peningkatan suhu di seluruh bagian bumi antara 0,150,30 derajat celcius. Bila pemanasan ini terus berlanjut, diperkirakan pada tahun 2040 lapisan es di kutub-kutub bumi akan habis meleleh. Akibatnya, diprediksi pada tahun 2050 akan terjadi kekurangan air tawar, sehingga kelaparan akan meluas, udara akan sangat panas, sehingga jutaan orang akan berebut air dan makanan (Majalah Serasi edisi 02, 2009: 5). Peringatan senada juga disampaikan Presiden RI Susilo Bambang Yudhoyono saat menyampaikan pidato pembukaan Pertemuan Sesi ke-11 Governing Council Global Ministerial Environment Forum United Nation Environment Programme (UNEP) di Bali pada bulan Mei 2010:

"Dalam 12 tahun terakhir, dunia mengalami kenaikan suhu tertinggi sejak tahun 1850. Kenaikan suhu sebesar itu akan mengakibatkan peningkatan permukaan air laut. Kita tidak dapat mengabaikan fakta ini.Kenaikan satu meter permukaan air laut, berdampak negatif terhadap jutaan orang yang hidup di bumi kita" (Majalah Serasi edisi 01, 2010: 5).

Lebih lanjut dikatakan, ada lebih dari 50.000 jenis tumbuhan mengalami kepunahan, hampir 4.000 spesies vertebrata endemic berpotensi hilang tak berbekas pada akhir abad ini, dan sekitar 60\% ekosistem dunia dari hutan dan lahan sampai karang laut dan sabana akan mengalami ker usakan serius (Majalah Serasi edisi 01, 2010: 5).

Kehancuran mata rantai kehidupan akibat kualitas bumi yang semakin merosot mengakibatkan rentetan bencana yang terjadi di tanah air, seperti tanah longsor yang menimbun desa di berbagai daerah hingga mengubur ratusan orang, terjangan banjir yang melumat pemukiman penduduk, kepungan asap akibat kebakaran hutan, kekeringan yang melanda sejumlah daerah serta rotasi musim yang semakin tidak pasti. Menurut Rachmat Witoelar, hal itu 
merupakan akibat perbuatan manusia sendiri dan menjadi isyarat bahwa kondisi bumi memang sudah kritis dan karena itu patut segera diselamatkan (Majalah Serasi edisi 02, 2009: 6).

\section{Dosa Monoteisme}

Berbagai kasus kerusakan alam yang terjadi baik dalam lingkup global maupun nasional, sebenarnya berakar dari perilaku manusia yang tidak bertanggungjawab terhadap lingkungannya. Manusia merupakan penyebab utama terjadinya kerusakan di permukaan bumi ini. Peningkatan jumlah penduduk dunia yang sangat pesat, mengakibatkan terjadinya eksploitasi intensif (berlebihan) terhadap sumber daya alam, hal ini memacu terjadinya kerusakan lingkungan terutama yang berupa degradasi lahan.Padahal lahan dengan sumberdayanya berfungsi sebagai penyangga kehidupan hewan dan tumbuhan termasuk manusia (PP Muhammadiyah \& Kementerian Lingkungan Hidup, $2011:$ 1).

Pengelolaan ekonomi tanpa penyelarasan implikasi sosial ekologisnya, yang ikut berperan penting dalam hilangnya jaminan keselamatan manusia dan keamanan sosial dalam proses perubahan ekonomi, telah mendorong perkembangan kegiatan-kegiatan produksi dan konsumsi sumber daya publik yang merusak lingkungan. Selain itu, perubahan ekologis yang sangat mendasar telah mengubah pula pola-pola dasar interaksi sosial.Konversi lahan pertanian ke lahan yang bersifat non-pertanian menyebabkan berkembangnya kegiatankegiatan publik yang tidak memiliki basis sejarah ekonomi masyarakat disinyalir mempercepat terjadi kerusakan ekologis di berbagai wilayah (Witoelar, 27 Maret 2008).

Orientasi hidup manusia modern yang cenderung materialistik dan hedonistik juga sangat berpengaruh.Pemusatan kehidupan pada rasionalitas dengan mengabaikan nilai-nilai tradisional yang berimplikasi pada pembangunan dalam segala bidang dan dilatarbelakangi semata-mata oleh motivasi ekonomi kapitalis. Hal ini telah membuat mata orang modern buta terhadap alam. Hanya nafsu terhadap alam saja yang berkobar menyala.Bahasa alam pun kini lenyap, berganti dengan kebutuhan ekonomi yang harus dipenuhi demi disebut "hidup menurut ukuran modern". Untuk memenuhi kebutuhan ekonomi, orang harus ikut dalam proses produksi, walaupun harus dengan menindas alam.

Kesalahan cara pandang atau pemahaman manusia tentang sistem lingkungannya, mempunyai andil yang sangat besar terhadap terjadinya 
kerusakan lingkungan yang terjadi di dunia saat ini. Cara pandang dikotomis yang memandang alam sebagai bagian terpisah dari manusia dan paham antroposentris, yang menganggap bahwa manusia adalah pusat dari sistem alam, mempunyai peran besar terhadap terjadinya kerusakan alam. Cara pandang antroposentris ini ternyata telah melahirkan perilaku yang eksploitatif dan tidak bertanggung jawab terhadap kelestarian sumberdaya alam dan lingkungannya. Disamping itu, paham materialisme, kapitalisme dan pragmatisme dengan kendaraan sains dan teknologi telah ikut pula mempercepat dan memperburuk kerusakan lingkungan baik dalam lingkup global maupun lokal, termasuk di negara kita (PP Muhammadiyah \& Kementerian Lingkungan Hidup, 2011: 1-2). Dalam konteks ini, monoteisme sering dikritik sebagai keyakinan yang kurang memiliki kepekaan terhadap alam dan lingkungan hidup. Lynn White Jr, sejarawan abad pertengahan, dalam buku "The Historical Roots of Our Ecologic Crisis" (1967) menuduh agama Kristiani sebagai agama yang paling antroposentris dalam memosisikan manusia berhadapan dengan alam (Harun, 1998: 65).

Dalam cara pandang Kristani abad pertengahan tentang manusia dan alam, manusia bukan bagian alam, tetapi penguasanya. Demi mandat budaya dari Tuhan, alam harus ditaklukkan dan dikuasai. Semasa abad pertengahan, kemenangan agama Kristiani atas Paganisme dirayakan berlebihan. Manusia tradisional memercayai hutan, gunung, dan alam ada penunggunya. Oleh karena itu, manusia tidak boleh sembarangan mengusik alam. Agama Kristiani menafikan kepercayaan kepada roh-roh seperti itu. Alam hanya ciptaan lebih rendah karena itu boleh dieksploitasi oleh ciptaan yang lebih tinggi. Dalam dualisme alam-manusia, alam ada hanya untuk manusia.

Dua tahun sebelum White, Harvey Cox, teolog dari Harvard, juga menuduh tradisi Kristiani dengan teologi penciptaannya, memisahkan alam dari Tuhan dan memisahkan manusia dari alam. Pemisahan tajam itu membuat manusia kehilangan rasa hormat kepada alam. Alam hanya untuk melayani kepentingan manusia dan obyek eksploitasi belaka (Karman, 23 November 2007).

Antroposentrisme atau antroposentrik secara literal bermakna "terpusat pada manusia"; sebuah terminologi yang digunakan dalam kaitan dengan humanisme ekstrim yang memandang dunia hanya dalam perspektif pengalaman manusia belaka (Runes, 6 Maret 2013). Doktrin antroposentrisme yang menekankan keterpisahan dan superioritas manusia dari pada alam ditegaskan dalam kisah penciptaan manusia dengan konsep imagodei (manusia 
citra Tuhan) dalam doktrin Yahudi dan Kristen (Harun, 1998: 65).

Dalam teologi Islam, antroposentrisme lingkungan hidup ditengarai berakar dari keyakinan Islam tentang manusia sebagai makhluk istimewa (super being), konsep manusia kuasa atas alam dan konsep manusia sebagai khalifah fi al ardh (Abdillah, 2006: 290). Doktrin superioritas antroposentrik inilah yang seringkali dijadikan legitimasi bagi manusia untuk melakukan segala tindakan atas alam, termasuk mengeksploitasinya.Tetapi benarkah doktrin keistimewaan manusia, kuasa atas alam, dan khalifah fi al ardh dalam Islam merupakan stempel bagi manusia untuk memperlakukan alam seenaknya?Bagaimana sesungguhnya konsep teologi Islam tentang relasi manusia-alam? Tulisan ini mencoba mengkaji posisi alam, posisi manusia, dan pola hubungan keduanya dalam pandangan Islam. Di sini penulis melakukan penelusuran dan analisis atas teks-teks keagamaan Islam, terutama al Quran dan al hadits yang terkait dengan hal itu.

\section{Pola Relasi Manusia dan Alam}

Menurut Robert P. Borrong, terdapat tiga pola perkembangan hubungan manusia dengan alam, yaitu:

a. Kesetaraan manusia dengan alam

Dalam masyarakat tradisional, manusia dan alam adalah sederajat. Hubungan keduanya relatif kontinuitas. Bahkan manusia sering merasa dirinya lebih kecil dari alam karena merasa sebagai gambaran alam semesta. Manusia adalah mikrokosmos dan alam sebagai makrokosmosnya. Manusia berusaha menyesuaikan diri dan menyelaraskan irama kehidupannya dengan alam semesta.Ini ditunjukkan dengan penyesuaian diri dengan musim dalam pertanian dan tidak berani mengganggu lingkungannya kecuali dengan ritual tertentu. Alam dianggap keramat dan kejam; karena itulah manusia sering menundukkan dirinya pada alam bahkan disembah-sembah sebagai dewa pemberi hidup.Pola hidup seperti ini seringkali berada di peradabanperadaban penyembah alam seperti di Mesopotamia, Mesir, Yunani, India, Jepang, Indian dan Jawa.Politeisme dan pateisme menjadi ciri spiritualitas kuno (Borrong, 2003: 65).

b. Manusia menguasai dan mengeksploitasi alam

Teknologi memungkinkan manusia dapat mengubah lingkungan alamiah menjadi lingkungan buatan. Manusia dapat mengubah alam sesuai kebutuhannya dengan menggunakan kemampuannya berbudaya. Makin tinggi kebudayaan manusia makin beragam kebutuhannya. Namun kebutuhan manusia sering 
tidak bisa dipisahkan dari keinginannya yang tak terbatas. Akibatnya ilmu pengetahuan dan teknologi digunakan untuk mengeksploitasi lingkungan alam dan eksploitasi itu menjadi tidak terbatas pula.

Kekuasaan manusia yang semakin besar atas alam ditandai oleh pesatnya pertumbuhan spesies manusia (demografi) dan pesatnya ilmu pengetahuan dan teknologi. Pertumbuhan kedua hal tersebut menyebabkan menipisnya sumber daya alam yang dieksploitasi untuk memenuhi kebutuhan dan keinginan umat manusia. Tiga faktor inilah (pertumbuhan demografi, ilmu pengetahuan/teknologi, dan menipisnya sumber daya alam) yang menjadi faktor-faktor penting dalam memahami terjadinya bencana alam. Dua faktor pertama (pertumbuhan demografi dan iptek) merupakan faktor-faktor yang menunjukkan keunggulan dan kekuasaan manusia atas alam sehingga menyebabkan kerusakan alam di zaman modern ini semakin cepat, massif, sistematis dan global.

Keinginan manusia yang tak terbatas melahirkan kerakusan (materialisme) yang mendorong pengeksploitasian tak terbatas terhadap sumber-sumber alam karena manusia mengambil dari alam lebih dari apa yang dibutuhkannya. Dalam posisi inilah manusia menjadi menguasai dan mendominasi alam. Hubungan manusia-alam menjadi bersifat hierarkis dan tidak lagi mencerminkan kesatuan, keharmonisan, keselarasan, dan keseimbangan antara keduanya. Manusia dengan ilmu pengetahuannya telah bebas dan merdeka dari pengaruh alam, dan sebaliknya, telah menjadi seolah-olah dewa dan tuhan atas alam (Borrong, 2003: 31-36).

c. Alam menguasai manusia

Meski iptek telah memposisikan manusia seolah-olah penguasa atas alam, namun ternyata manusia tidak benar-benar menguasai alam, justru seringkali alam yang menguasai manusia.Berbagai bentuk bencana alam yang terjadi ternyata menjadi bencana bagi manusia, dan ilmu pengetahuan dan teknologi yang dikuasai manusia ternyata tidak juga membuat manusia berhasil menundukkan alam (Borrong, 2003: 38).Yang terjadi justru manusia menjadi tidak berdaya atas alam dengan bencana-bencana yang menimpanya dan manusia juga menjadi tergantung pada alam lain yang tercipta dari rekayasa sains-teknologi.

\section{Posisi Alam \& Manusia dalam Islam}

Hal mendasar dalam keyakinan Islam adalah kenyataan bahwa alam semesta merupakan sesuatu yang riil secara eksistensial, bukan ilusi atau 
bayang-bayang semu sebagaimana yang digambarkan oleh Plato. Plato melihat dunia terbagi dua: 1). Dunia Indera yang selalu berubah dan tidak kekal. Tidak ada sesuatu yang selalu ada dalam dunia ini. Semua hal datang dan pergi.Dunia ini bisa ditangkap oleh indera. 2). Dunia Ide. Dunia ini kekal dan abadi. Kita tidak bisa menggunakan indera untuk menangkapnya.Hanya akal yang bisa mengenalinya. (Gaarder, 2006: 107-108). Meskipun demikian alam bukanlah Tuhan atau dewa-dewa yang berkuasa atas manusia sehingga manusia perlu memuja-muja atau menyembahnya. Pandangan hidup Islam (tauhid) menempatkan alam sebagai ciptaan (makhluk) yang eksistensinya tergantung pada Sang Khalik yang telah mencipta dan merawatnya.Tauhid bermakna menafikan setiap kekuatan yang beroperasi di alam ini selain dari Tuhan.Ini berarti penolakan terhadap setiap kekuatan selain Tuhan yang mengatasi semua hal. Melalui Tauhid, alam dibedakan dari roh-roh dan dewa-dewa agama primitif (Faruqi, 1992: 52). Terkait penciptaan alam ini bisa dirumuskan dalam tiga poin(Muhammad, dkk., 2006: 17):

1. Pencipta alam semesta adalah Rabb Semesta Alam, yaitu Rabb yang sebenarnya, Rabb Yang Maha Esa (QS. al Syu'ara : 23-24, al Anbiya: 56, al Shaffat: 4-5).

2. Allah SWT Pencipta langit dan bumi, dan cukup dengan mengatakan "Kun!", dengan kehendakNya sendiri, dan tak ada yang membantu-Nya (QS. al Zumar: 38, al Baqarah: 117, al Rum: 25, al Fathir: 40).

3. Allah SWT yang membina ciptaanNya, menyempurnakan ciptaan-Nya, dan Dia pula yang memelihara ciptaanNya, sekaligus menahannya agar tidak lenyap (QS. al Nazi'at: 27-28, al Zukruf : 7, al Naba: 37, al Fathir: 41).

Allah mencipta alam dengan sungguh-sungguh, tidak main-main di dalam QS. al Anbiya: 16, al Ankabut: 44, al Ahqaf: 3 dan dalam pola-pola tertentu yang teratur di dalam QS. al Furqan: 2, al Qamar: 49. Selain sebagai ciptaan, alam adalah karunia Tuhan sebagai tempat pembuangan yang baik dan tanpa dosa (innocent) bagi manusia.Alam diciptakan dengan tujuan agar manusia bisa melakukan kebaikan dan meraih kebahagiaan (Faruqi, 1992: 50). Berikut ini beberapa tujuan keberadaan alam menurut al Quran (Muhammad, dkk., 2006: 17):

a. Tanda kekuasaan Allah bagi yang berakal (QS. Ali Imran: 190)

b. Tanda kekuasaan Allah bagi yang mengetahui (QS. al Rum: 22)

c. Tanda kekuasaan Allah bagi yang bertakwa (QS. Yunus: 6)

d. Tanda kekuasaan Allah bagi yang mau mendengarkan pelajaran (QS. al Nahl: 65 
e. Tanda kekuasaan Allah SWT bagi yang memikirkan (QS. al Ra'd: 3)

f. Untuk memenuhi kebutuhan hidup manusia (QS. al Baqarah: 29)

g. Sebagai suatu rahmat dari Allah (QS. al Jatsiah: 13)

h. Untuk kepentingan manusia (QS. Luqman: 20)

i. Untuk menyempurnakan nikmat dan ujian bagi semua manusia (QS. Hud: 7)

j. Untuk mengetahui siapa-siapa yang lebih baik amalannya dalam hidup ini (QS. al Mulk :2)

Alam semesta terbentang penuh dengan hukum-hukumnya (these laws of nature) sesuai dengan perintah dan kehendak Tuhan.Karena itu, alam semesta merupakan tempat teater kehidupan yang bergerak oleh perintah dan tindakan Tuhan. Ini karena Tuhan dalam konsep Islam adalah Tuhan yang hidup, aktif, dan selalu hadir di setiap waktu.Tuhan adalah satu-satunya agen tertinggi (sole ultimate agent) dan sebab puncak dari semua wujud (Faruqi, 1992: 51-52).

Sebagai salah satu makhluk biologis, manusia berasal dari tanah, bumi, tanah liat, tanah kering, saripati tanah, atau sejenisnya sebagaimana yang terungkap dari banyak ayat al Quran, seperti QS. an Nuh: 17-18, at Taha: 55, Hud: 61, al Rahman: 14, al Hijr: 26, al Mu'minun: 12 dan al Furqan: 54. Proses kelanjutan dan perkembangan manusia (reproduksi) kemudian diciptakan dari air mani dijelaskan dalam QS. al Qiyamah: 37, al Mu'minun: 14, air mani yang bercampur dalam QS. al Insan: 2, air yang hina dalam QS. al Sajdah: 8. Bentuk biologis itu secara substansial menjadi manusia dengan peniupan ruh ke dalamnya (QS. al Hijr: 28-29).

Manusia sebagai makhluk Allah SWTpar excellence,diciptakan dalam bentuk yang sebaik-baiknya dalam QS. al Tin: 4 dan telah dimuliakan oleh Allah SWT dengan beberapa keutamaan atas makhluk-makhluk ciptaan Allah SWT yang lainnya (QS. al Isra: 70).

"Sungguh, Kami telah menciptakan manusia dalam bentuk yang sebaikbaiknya”(QS. al Tin: 4).

"Dan sungguh, Kami telah memuliakan anak cucu Adam, dan Kami angkat mereka di darat dan di laut, dan Kami beri mereka rezeki dari yang baik-baik dan Kami lebihkan mereka di atas banyak makhluk yang Kami ciptakan dengan kelebihan yang sempurna" (QS. al Isra:70). 
Manusia juga telah dibekali sifat fitrah yang disebutkan di dalam QS. al Rum: 30 dan hanif (cenderungan kepada kebenaran) yang ditegaskan dengan ikrar kesaksian pada ketauhidan saat manusia berada di dalam rahim.

"Dan (ingatlah), ketika Tuhanmu mengeluarkan dari sulbi (tulang belakang) anak cucu Adam keturunan mereka dan Allah mengambil kesaksian terhadap roh mereka (seraya berfirman): "Bukankah Aku ini Tuhanmu?" mereka menjawab: "Betul (Engkau Tuhan kami), kami bersaksi". (Kami lakukan yang demikian itu) agar di hari kiamat kamu tidak mengatakan: "Sesungguhnya ketika itu kami lengah terhadap ini" (QS. al A'raf: 172).

Kata fitrah berasal dari akar kata fitr. Arti kata ini adalah "keawalmulaan sesuatu sementara sebelumnya sesuatu itu tidak ada". Dengan kata lain, "sesuatu yang tercipta untuk pertama kalinya dan tanpa preseden (contoh)". Sinonimnya adalah al khalq atau al ibda'. Contohnya, air susu yang pertama kali keluar dari induk unta disebut sebagai fitr. Maka, dalam ayat di atas QS. al Rum: 30, fitrah berarti unsur manusia yang diciptakan pertama kali. Fitrah manusia itu tidak pernah berubah sepanjang hidupnya/selama-lamanya. Bukan kebetulan juga bahwa makna lain kata fitrah adalah cetakan atau patrian, yang sekali dicetak atau dipatri, tak akan bisa diubah atau dilepaskan.

Bukan saja bahwa fitrah manusia merupakan perwujudan ruh Allah SWT, tapi ia juga identik dengan agama itu sendiri, tepatnya "agama yang lurus". Yakni, suatu pandangan dunia (world-view atau weltanscahauung) dan cara hidup (way of life) yang benar, yang berorientasi keimanan kepada Allah SWT, dan kepada kebenaran suatu cara pandang dan cara hidup yang, dalam ayat yang sama, disebut juga dengan cara hidup yang hanif.

Fitrah memiliki dua unsur utama dan fundamental; Pertama, keimanan kepada Tuhan sebagai Rabb (Pencipta dan Perawat) (QS. al A'raf: 172). Kedua, pengetahuan tentang jalan kebaikan dan jalan keburukan yang telah diilhamkan kepada manusia sejak awal penciptaannya:

"Demi jiwa serta penyempurnaan (ciptaan)Nya, maka Dia mengilhamkan kepadanya (jalan) kejahatan dan ketakwaannya, sungguh beruntung orang yang menyucikannya (jiwa itu), dan sungguh rugi orang yang mengotorinya" (QS. al Syams: 7-10).

Maka setiap manusia diciptakan dengan kecenderungan bawaan beriman kepada Allah SWT dan kepemilikan pengetahuan tentang kebaikan atau ketakwaan dan keburukan (Bagir, 28 Pebruari 2013). Sisi keunggulan inilah 
yang menempatkan manusia layak menerima amanat kekhilafahan dari Allah SWT di muka bumi, sebagaimana disebutkan di dalam al Quran:

"(Dan) ingatlah ketika Tuhanmu berfirman kepada para malaikat: "Aku hendak menjadikan seorang khalifah di muka bumi." Mereka berkata: "Apakah Engkau hendak menjadikan orang yang merusak dan menumpahkan darah di sana, sedangkan kami bertasbih memuji-Mu dan menyucikan nama-Mu?." Dia berfirman: "Sungguh, Aku mengetahui apa yang tidak kamu ketahui"(QS. al Baqarah: 30).

"Dan Dialah yang menjadikan kamu penguasa-penguasa di bumi dan dia mengangkat (derajat) sebagian kamu di atas yang lain, untuk mengujimu (atas karunia) yang diberikanNya kepadamu. Sesungguhnya Tuhanmu sangat cepat memberi hukuman dan sungguh, Dia Maha Pengampun, Maha Penyayang”(QS. al An'am: 165).

Dalam dunia mistik Islam (tasawuf), keistimewaan manusia terletak pada kehormatan manusia sebagai hasil kerja Tuhan yang sempurna, hidup melalui tiupan nafasNya, dan menjadi cermin bagi kualitas-kualitas ketuhanan. Hal itu disimbolkan dengan Adam (bapak umat manusia) sebagai manusia sempurna (the perfect man) yang dikaruniai kehormatan spesial berupa pengetahuan sebagaimana yang termaktub dalam QS. al Baqarah: 31. Allah SWT mengajari Adam nama-nama banyak hal berarti Adam diberi kemampuan untuk mengatur dan menggunakannya untuk kepentingannya. Dengan sifat pengetahuan itulah Adam menjadi penguasa (master) atas semua ciptaan. Lebih jauh, manusia adalah mikrokosmos dan diciptakan untuk kepentingan Tuhan, dan Tuhan mencipta semua hal untuk kepentingan manusia (Schimmel, 1975: 188). Konsep inilah yang dianggap oleh sebagian orientalis sebagai sebentuk antropologi Islam yang sangat berbahaya (Schimmel, 1975: 187).

\section{Relasi Manusia dan Alam}

Secara eksistensial manusia tetaplah ciptaan (makhluk) layaknya ciptaanciptaan Allah SWT yang lainnya. Eksistensi manusia sebagai makhluk tidak pernah berubah hanya karena ia telah diangkat oleh Allah SWT sebagai khalifahNya. Pada titik ini manusia dan alam adalah dua hal yang sama; makhluk ciptaan Allah yang sama-sama menjadi bukti eksistensi ketuhanan (QS. al Fushshilat: 53). Sebagai sesama makhluk, manusia dan alam samasama tunduk pada kekuasaan Allah SWT, memuji dan bertasbih kepada-Nya sebagaimana disebutkan di dalam al Quran: 
"Dan segala apa yang berada di langit dan apa yang ada di bumi hanya bersujud kepada Allah, yaitu semua makhluk bergerak (bernyawa) dan (juga) para malaikat, dan mereka (malaikat) tidak menyombongkan diri” (QS. al Nahl: 49).

"Langit yang tujuh, bumi dan semua yang ada di dalamnya bertasbih kepada Allah. Dan tidak ada sesuatupun melainkan bertasbih dengan memuji-Nya, tetapi kamu tidak mengerti tasbih mereka. Sungguh, Dia Maha Penyantun, Maha Pengampun” (QS. al Isra: 44).

Kedekatan relasi manusia-alam dalam Islam tergambarkan pada berbagai ritual ibadah yang wajib dijalani umat muslim yang seringkali terkait dengan pergerakan alam; waktu-waktu shalat wajib ditentukan sesuai pergerakan spesifik matahari tercantum di dalam QS. al Isra: 78, at Taha: 130, Qaaf: 39, demikian juga dengan waktu pelaksanaan haji di dalam QS. al Baqarah: 189 dan penentuan bulan puasa yang berpedoman pada peredaran bulan di dalam QS. al Baqarah:185.

Peran penting alam bagi kehidupan manusia juga tersimbolkan pada posisi Ka'bah, tempatumat muslim menghadapkan dirinya pada Allah SWT, yang berada di titik pusat bumi. Islam juga memandang bumi ini sebagai tempat untuk menyembah Allah SWT (masjid) dan alat bersuci sebagaimana di dalam surat:

"Jabir bin Abdillah r.a. berkata bahwa Nabi Muhammad SAW bersabda, "Aku diberi lima hal yang tidak diberikan kepada seorang (nabi) pun sebelumku. Aku ditolong dengan ditimbulkan ketakutan (kepada musuh) dari jarak satu bulan, dijadikanNya bumi bagiku sebagai masjid (tempat shalat) dan suci. Siapa pun dari umatku masuk waktu shalat, hendaklah ia shalat; dihalalkan-Nya rampasan perang bagiku, padahal rampasan itu tidak halal bagi seorang pun sebelumku; aku diberi syafa'at, dan nabi (selain aku) diutus khusus kepada kaumnya saja, sedangkan aku diutus kepada manusia pada secara umum (dalam satu riwayat: keseluruhan)" (HR. Bukhari).

\section{Tugas Sang Khalifah}

Meski manusia dan alam memiliki titik-titik kesamaan, namun tetaplah manusia memiliki sisi-sisi keunggulan yang membuat dirinya terpilih sebagai pemegang amanat sebagai khalifah di bumi ini, khalifah berarti pengganti (Baalbaki, 1995: 519). Kata ini berasal dari kata khalafa yang bermakna mengganti, menjadi pengganti, mengikuti, datang setelah, dan lain sebagainya (Baalbaki, 1995: 521). Dengan demikian khalifah Allah fi al ardh berarti 
pengganti Allah SWT di muka bumi.

Doktrin khalifah fi al ardh sering dinilai sebagai sumber antroposentrisme dalam Islam, dan menjadi alat legitimasi bagi proses eksploitasi dan perusakan terhadap alam, apalagi beberapa ayat al Quran menyatakan bahwa alam semesta diciptakan untuk kepentingan manusia sebagai sang khalifah yang tercantum di dalam QS. al Baqarah: 29, al Jatsiah: 13 dan Luqman: 20.

Namun anggapan itu sesungguhnya tidak memiliki basis teologis yang kuat jika kita memperhatikan ayat-ayat al Quran lainnya yang terkait dengan posisi manusia dan tugasnya tersebut. Dalam konteks ini manusia adalah pengganti Allah SWT di muka bumi yang memiliki beberapa tugas, yaitu:

a. Beribadah kepada Allah

"Dan Aku tidak menciptakan jin dan manusia melainkan agar mereka beribadah kepada-Ku” (QS. al Dhariyat: 56).

b. Memakmurkan bumi

"Dan kepada Samud (Kami utus) saudara mereka, Saleh. Dia berkata: "Wahai kaumku! sembahlah Allah, tidak ada tuhan bagimu selain Dia. Dia telah menciptakanmu dari bumi (tanah) dan menjadikanmu pemakmurnya, karena itu mohonlah ampunan kepada-Nya, kemudian bertobatlah kepada-Nya. Sesungguhnya Tuhanku amat dekat (rahmat-Nya) dan memperkenankan (doa hamba-Nya)" (QS. Hud: 61).

c. Menegakkan keadilan dan tidak mengikuti hawa nafsu

"(Allah berfirman), 'Wahai Dawud, sesungguhnya engkau Kami jadikan khalifah (penguasa) di bumi, maka berilah keputusan (perkara) diantara manusia dengan adil dan janganlah engkau mengikuti hawa nafsu, karena akan menyesatkan engkau dari jalan Allah. Sungguh, orang-orang yang sesat dari jalan Allah akan mendapat azab yang berat, karena mereka melupakan hari perhitungan" (QS. Shad: 26).

Orang yang mengikuti hawa nafsu adalah orang yang mengikuti dorongan jelek jiwa yang telah diharamkan oleh hukum syariat; mengikuti hawa nafsu untuk melakukan perbuatan-perbuatan yang dilarang hukum syara'. Itba' al hawa merupakan pangkal perbuatan maksiat, sumber malapetaka dan kemungkaran. Orang yang bersikap demikian akan tersesat dari jalan Allah SWT dan dikenai siksa di akhirat kelak (Madary, tgl 1 Maret 2013).

Dengan demikian, posisi khalifah bagi manusia bukanlah alat bagi manusia untuk bisa berbuat apapun yang dikehendakinya atas alam ini, meskipun Allah SWT telah menyediakan semua yang ada untuk manusia. Pernyataan al Quran bahwa alam diciptakan untuk manusia sebagaimana 
termaktub dalam QS. al Rahman: 10 dan al Baqarah: 29, bukanlah penegasan kebolehan manusia berbuat semaunya terhadap alam. Kata "lam" dalam ayat-ayat tersebut adalah "lam li tanfi" (hak memanfaatkan), bukan "lam li tamlik" yang bermakna memiliki. Karena itu dapat dipahami manusia diberi hak dan wewenang oleh Allah SWT untuk memanfaatkan alam dalam batasbatas ekologis sebab manusia bukan pemilik hakiki alam ini.Pemilik yang sah adalah Allah SWT (Abdillah, 2006: 292).

Dengan tiga tugas yang disematkan pada manusia itu, posisi khalifah justru merupakan amanat bagi manusia untuk menjaga kelestarian alam ini.Berbagai tugas yang menyertai peran sebagai khalifah di muka bumi menuntut manusia untuk menjalin hubungan harmoni dengan alam, menjaga keseimbangan dan keteraturan alam, serta tidak melakukan eksploitasi yang berlebihan sehingga merusak alam itu sendiri. Hal ini ditegaskan oleh Allah SWT dalam berbagai ayat al Quran, seperti dalam QS. al A'raf: 56, 74, 85, dan QS. al Syu'ara: 151-152.

"Dan janganlah kamu membuat kerusakan di bumi, setelah (diciptakan) dengan baik.Berdo'alah kepadaNya dengan rasa takut dan penuh harap. Sesungguhnya rahmat Allah sangat dekat kepada orang yang berbuat kebaikan" (al A'raf : 56).

Pelaku perusakan alam dikategorikan sebagai orang-orang yang melampaui batas:

"Dan janganlah kamu menaati perintah orang-orang yang melampaui batas, yang berbuat kerusakan di bumi dan tidak melakukan perbaikan" (QS. al Syu'ara: 151-152).

Israf (subjek: musrif, bentuk plural: musrifun atau musrifin) berarti melebihi batas-batas kepantasan, pergi terlalu jauh, bersikap ekstrem, boros/ royal, tidak moderat, berlebih-lebihan, atau melakukan sesuatu dengan berlebih-lebihan (Baalbaki, 1995: 105). Dengan demikian, kerusakan yang dilakukan oleh manusia atas alam ini terjadi karena sikap hidup manusia yang melampaui batas-batas kewajaran hidupnya, melebihi batas-batas kebutuhannya, dan perilaku yang boros. Senada dengan itu, ayat lain juga menyebut mereka sebagai orang-orang fasik yang pasti mendapatkan kerugian:

“.... dengan perumpamaan itu banyak orang yang dibiarkanNya sesat, dan dengan itu banyak (pula) orang yang diberiNya petunjuk. Tetapi tidak ada yang Dia sesatkan dengan (perumpamaan) itu selain orang-orang fasik, (yaitu) 
orang-orang yang melanggar perjanjian Allah setelah (perjanjian) itu diteguhkan, dan memutuskan apa yang diperintahkan Allah untuk disambungkan, dan membuat kerusakan di bumi. Mereka itulah orang-orang yang rugi” (QS. al Baqarah: 26-27).

Kata "Fasik" (fasiq) berasal dari bahasa Arab "fasaqa" atau "fasuqa" yang bermakna hidup berfoya-foya, hidup penuh dengan tindakan amoral, penuh dengan dosa, risau, atau tersesat (Baalbaki, 1995: 825). Pelaku perbuatan "fasaqa" (yaitu: fasiq) memiliki makna yang merisau, yang berfoya-foya, yang tidak bermoral, yang ceroboh, pelepas nafsu birahi, dan berbagai makna negatif lainnya (Baalbaki, 1995: 812). Dengan berbagai atribut negatif yang tersimpan dalam diri orang-orang fasik itulah, maka sangat wajar jika mereka akan mendapat kerugian dalam hidupnya.

Merusak alam merupakan suatu dosa yang berposisi setingkat di bawah dosa memusuhi Allah SWT dan Rasul, dengan ancaman hukuman mati, disalib, dipotong tangan dan kakinya berselang-seling, atau diasingkan, sesuai dengan tingkat kerusakan alam yang ditimbulkannya, serta ancaman hukuman setimpal di akhirat kelak:

"Hukuman bagi orang-orang yang memerangi Allah dan rasul-Nya dan membuat kerusakan di bumi, hanyalah dibunuh atau disalib, atau dipotong tangan dan kaki mereka secara silang, atau diasingkan dari tempat kediamannya.Yang demikian itu kehinaan bagi mereka di dunia, dan di akhirat mereka mendapat azab yang besar"(QS. al Maidah: 33).

Selain hukuman melalui tangan manusia lain tersebut, Allah SWT juga akan memberikan siksa secara langsung kepada manusia melalui "tangan" alam itu sendiri; seperti pemanasan global, angin puting beliung, banjir, longsor dan lain-lainnya:

"Telah nampak kerusakan di darat dan di laut disebabkan karena perbuatan tangan manusia; Allah menghendaki agar mereka merasakan sebagian dari (akibat) perbuatan mereka, agar mereka kembali (ke jalan yang benar" (QS. al Rum: 41).

Bahkan tindakan perusakan atas alam yang dilakukan manusia akan menjadi sebab dicabutnya hak kepemilikan dan penguasaan manusia atas alam ini. Karena Allah hanya akan menyerahkan alam kepada orang-orang yang salih. 
"Dan sungguh, telah Kami tulis di dalam Zabur setelah (tertulis) di dalam Az Zikr (Lauh al Mahfuz), bahwa bumi ini akan diwarisi oleh hamba-hamba-Ku yang saleh" (QS. al Anbiya': 105).

Secara literal kata "salih" bermakna: baik, benar, valid, tepat, kompeten, cakap, berbudi luhur, bermanfaat, jujur (Baalbaki, 1995: 656). Kata ini berasal dari huruf "Shad-Lam-Ha" yang bisa dibaca salaha atau saluha dengan makna menjadi baik, benar, berbudi luhur, dan seterusnya.Jika dibaca "sallaha" (dengan lam dobel) berarti damai atau tindakan mendamaikan (Baalbaki, 1995: 699). Sedang jika shadnya difathah dan dibaca panjang "saalaha", memiliki arti: "berdamai dengan"(Baalbaki, 1995: 656). Sedang kata waris berasal dari kata "wa-ra-tsa" yang berarti mewarisi (Baalbaki, 1995: 1228) .Dengan demikian, hanya orang-orang yang mampu berbuat baik, berbudi luhur, memiliki kompetensi dan mampu hidup damai dengan alam saja yang berhak tinggal, memiliki dan mengelola bumi ini.

Ketegasan Allah SWT melarang manusia merusak alam dengan berbagai ancaman hukuman di dunia dan akhirat terjadi karena tindakan itu (merusak alam) merupakan kejahatan yang dapat menghancurkan umat manusia dan kemanusiaan.

"Oleh karena itu kami tetapkan (suatu hukum) bagi Bani Israil, bahwa barang siapa membunuh seseorang, bukan karena orang itu membunuh orang lain, atau bukan karena membuat kerusakan di bumi, maka seakan-akan dia telah membunuh semua manusia.Barangsiapa memelihara kehidupan seorang manusia, maka seakan-akan dia telah memelihara kehidupan semua manusia. Sesungguhnya Rasul Kami telah datang kepada mereka dengan (membawa) keterangan-keterangan yang jelas. Tetapi kemudian banyak diantara mereka setelah itu melampaui batas di bumi” (QS. al Maidah: 32).

\section{Simpulan}

Di satu aspek, hubungan manusia-alam dalam Islam mirip pola hubungan pertama yang memosisikan manusia sederajat dengan alam bahwa manusia dan alam adalah sama-sama makhluk ciptaan Allah SWT yang menjadi ayat (tanda) bagi eksistensi-Nya. Namun kemiripan itu tetap tidak sampai menjadikan manusia sebagai bagian (subordinasi) dari alam sehingga manusia perlu menjadikan alam sebagai pengendali hidupnya (sebagai dewa-dewa), karena manusia dan alam hanya sekedar makhluk yang tunduk patuh dan memuja Allah SWT. Ini adalah titik utama yang membedakan pandangan Islam dengan keyakinan yang ada dalam kebudayaan animisme-panteisme 
yang dianut beberapa kepercayaan kuno.

Di sisi lain pola hubungan manusia-alam juga mirip dengan pola kedua dimana manusia menjadi penguasa atas alam; bahwa al Quran menempatkan manusia lebih tinggi dari alam dengan bentuknya yang sempurna (ahsan al taqwim), memiliki beberapa keistimewaan yang tidak dimiliki makhluk lain sehingga manusia diangkat oleh Allah SWT sebagai penggantiNya di bumi (khalifah Allah fi al ardh), dan hak manusia untuk memanfaatkan alam untuk kebutuhannya karena alam sengaja diciptakan Allah SWT untuk kebutuhan manusia.

Meski demikian, kemiripan itu tidak secara seratus persen sebagaimana yang terjadi pada penguasaan manusia atas alam dalam kehidupan manusia modern, dimana manusia merasa seolah-olah menjadi "Tuhan" atas alam yang berhak berbuat semena-mena atasnya. Penguasaan manusia atas alam, dalam konteks Islam, dibatasi oleh kenyataan bahwa posisi istimewa itu merupakan amanat Allah SWT kepada manusia dengan berbagai tugas yang menjadi "tali kekang" bagi manusia dalam memperlakukan alam; bahwa kekuasaan manusia atas alam digunakan sebagai sarana bagi manusia untuk mengabdi pada Allah SWT, bukan untuk mengeksploitasinya secara semena-mena demi memuaskan nafsu keserakahannya (materialisme). Allahu a'lam.

\section{Daftar Pustaka}

Abdillah, Mujiyono, 2006. Rekonstruksi Teologi Lingkungan dalam Pembangunan Masyarakat Madani. Jurnal Innovatio. Volume 5, Nomor 10: 280-292.

Baalbaki, Rohi, 1995. Al Mawrid a Modern Arabic-English Dictionary. Beirut: Dar al Ilm li al Malayin.

Bagir, Haidar. Diakses tanggal 28 Pebruari 2013. "Fitrah dan Kebahagiaan". Http://mizan.com/index.php?fuseaction=plong\&id $=44$.

Borrong, Robert P. 2003. Etika Bumi Baru. Jakarta: BPK Gunung Mulia.

Departemen Agama. Tt. Al Quran dan Terjemahnya. Jakarta: PT Syamil Cipta Media.

Faruqi, Al, Isma `il Raji. 1992. Al Tawhid; its Implications for Thought and Life. Virginia: International Institute of Islamic Thought.

Gaarder, Jostein. 2006. Dunia Sophie: Sebuah Novel Filsafat. Diterjemahkan oleh Rahmani Astuti. Bandung: Mizan. 
Harun, Martin. 1998. Taklukkanlah Bumi dan Berkuasala. Jurnal Pelita Zaman. Volume 13, Nomor 2. http://alkitab.sabda.org/resource.php.

Karman, Yonky. 23 November 2007. Teologi Ramah Lingkungan. Kompas.

Madary, El, Ibnu Dahlan. Diakses tanggal 1 Maret 2013. "Hawa Nafsu (Itba' al Hawa) dan Penjelasannya”. Http://tanbihun.com

Majalah Serasi. Edisi 01/2010.

Majalah Serasi. Edisi 02/2009.

Muhammad, Ahsin Sakho, dkk (editor). 2006. Fiqh Lingkungan (Fiqh al Bi'ah). Jakarta: Conservation International Indonesia.

PP Muhammadiyah, Majelis Lingkungan Hidup. 2011. Teologi Lingkungan: Etika Pengelolaan Lingkungan dalam Perspektif Islam. Jakarta: PP Muhammadiyah \& Kementerian Lingkungan Hidup.

Ringkasan Shahih Bukhari (versi hadits Web 4.0).

Runes, Dagobert D. Diakses tanggal 6 Maret 2013. Dictionary of Philosophy. Http://www.ditext.com/runes/a.html.

Schimmel, Annemarie. 1975. The Mystical Dimensions of Islam. Chapel Hill: The University of North Carolina Press.

Umar, Nasaruddin. 2001. Argumen Kesetaraan Jender. Jakarta: Paramadina.

Witoelar, Rachmat. 27 Maret 2008. Isu Perubahan Iklim: Pencetus Perubahan Pengelolaan Lingkungan Hidup Ke Arah yang Lebih Baik. Http://www. setneg.go.id. 